\title{
SOCIAL WORKERS' COMPENSATION MODELS AND THE CZECH STATUTORY EMPLOYER LiABILITY INSURANCE
}

\author{
Jaroslav Vostatek ${ }^{1}$
}

\begin{abstract}
Czech workers' compensation is "exemplified" by the adoption of the Worker's Accident Insurance Act in 2006, four deferments of its effective date and then complete annulment of the Act. A temporary settlement aimed at resolving the incompatibility of the communist model of workers' compensation for work accidents and occupational illnesses with the transition to a market economy after 1989 involved the implementation of statutory employer liability insurance for work accidents and occupational illnesses, outsourced to two private insurance companies; the current Czech government does not seem to have a know how to deal with it. The objective of this paper is primarily to advise the government using primarily the formulation and comparison of four basic social workers' compensation models and furthermore considering the existing sickness, pension and health insurance systems. The choice of a social model is namely a matter of public choice, but intensive lobbying also constitutes part of these processes. The analyses result in a recommendation to "dissolve" the statutory employer liability insurance into a jointly collected social insurance contribution for sickness and pension insurance, and partly to transform the current accident benefits into increased sickness and pension benefit assessments and partly to cancel them.
\end{abstract}

\section{Keywords}

Workers' Compensation, Welfare Regimes, Social Accident Insurance, Czech Social Reforms, Beveridge, Bismarck

\section{Introduction}

The Czech statutory liability insurance for compensation of work accidents and occupational illnesses was introduced as a stopgap measure after 1989 and it still exists in Czechia today. The general consensus is that this involves a completely non-systemic (and even unconstitutional) element, because the state (de facto represented by the Ministry

\footnotetext{
${ }^{1}$ University of Finance and Administration, Estonská 500, 10100 Prague 10, Czech Republic.

E-mail: jaroslav.vostatek@vsfs.cz.
} 
of Finance) has outsourced the agenda of collecting the insurance contributions and providing the benefits from this "statutory" insurance to two private insurance companies according to a historic key and subject to a fee, the initial amount of which was wildly incommensurate and was only reduced to a relatively acceptable level several years ago on the basis of a proposal from a communist MP. In addition, this includes differentiated insurance premium rates which have been valid for more than 25 years. It is quite clear that (not only) this type of public insurance has been the subject of a struggle between several interest groups as for its administration.

This paper is not primarily interested in looking for "a single correct" reform of the Czech statutory employer liability insurance for work accidents and occupational illnesses. On the contrary, we have proceeded from the fact that several social models (welfare regimes) exist which typically manifest themselves, for example, in the funding of pension schemes or in the systems for the provision and financing of healthcare. As such we have differentiated between three models according to Esping-Andersen (1990) and we have added a fourth, the neo-liberal social model, which has developed in recent decades. At the same time, we have also proceeded from the fact that the choice of a general social model is a typical public choice. This does not, of course, prevent us from objectively evaluating the application of the individual social models in our country: both in general and with regard to the individual branches of social security, including any benefits paid out in the case of work injuries and occupational illnesses. These analyses will then enable us to propose another approach to the segment of statutory liability insurance for work accidents and occupational illnesses.

\section{The liberal social compensation model}

The classic liberal social model did not consider work accidents to constitute a distinctively specific issue. As such, the principle of legal fault (the tort system) prevailed. However, this tort system failed in the compensation for work injuries also in Great Britain in the 19th century, which was the main reason for the creation of a no-fault system alongside the tort system. The Act from 1897 introduced compulsory limited benefits paid by the employer in the case of work accidents based on negligence. It was up to the employers how they insured themselves against such a case. This system is considered to be the "pioneer of social security", because it became the predecessor to the widely conceived social system. The system's basic concept remained in force in Great Britain until 1948, when the state assumed this liability (Lewis, 2012).

The system of relatively low state universal benefits, as created by the Beveridge Committee in 1942 and implemented in Great Britain in 1948, can be considered to constitute a modern version of the liberal model. The starting thesis was a uniform scheme for incapacity to work and invalidity regardless of the cause thereof. The counter argument was the importance of many branches of the economy with high-risk jobs, the performance of employment activities at somebody's behest and the specific option of limiting an employer's liability for any negligence (Lewis, 2012). 
The British system of state pensions did not and still does not include an independent, general invalid's pension. The employer pays Statutory Sick Pay, from April 2020 at the amount of $£ 95.85$ per week, throughout a period of incapacity to work of up to 28 weeks. The alternative is participation in an occupational sick pay scheme. The followup Employment and Support Allowance (ESA) was implemented in 2008 and it was also made available to invalids. The new Universal Credit (UC) system of means-tested social benefits is gradually being rolled out in the individual regions from 2018 to 2022. This takes the form of an integrated rebate on income tax, into which the ESA has also been incorporated as one of 4 benefits in addition to the basic UC tax allowance under the designation of the "disability element".

If an employee suffers a work injury in Great Britain, he or she is entitled to an Industrial Industries Disablement Benefit (IIDB) which is part of the "national insurance" scheme; the full amount of the benefit (given 100\% disablement) is currently $£ 182$ per week. Disablement as a consequence of a work accident is graded by increments of $1 \%$, while the minimum extent of disablement required for an entitlement to the benefit is $14 \%$. Two types of additional benefits are also paid out in the case of full disablement and the need for personal care: a Constant Attendance Allowance (CAA, 4 levels of benefit) in the case of needed daily care and an Exceptionally Severe Disablement Allowance in the case of needed permanent care. For the purposes of comparison, the current amount of the full state old-age pension is $£ 175.20$ per week, the Industrial Injuries Disablement Benefit is only by $3.9 \%$ higher!

A British employee may also receive further compensation for a work injury from his or her employer. Since 1972, the private sector has been obliged to have concluded an employer liability (EL) insurance policy. This insurance is associated with high court costs. The introduction of compulsory liability insurance for work injuries and occupational illnesses can be considered as an expression of the inadequacy of the universal social security benefits in the modern liberal social model.

\section{Christian-democratic social compensation models}

The Christian-democratic social model is based on the differentiated need of securing individual social groups and as such it results in segmented compensation for work injuries and occupational illnesses of the individual social groups. The best-known submodel here is social accident insurance as one of the (3-5) branches of employee social insurance which is designated for employees of the private sector. A special feature of this social accident insurance scheme involves its material overlap with the other branches of social insurance: the accident insurance provides health care and cash benefits during any incapacity to work, disablement etc. as a consequence of a work accident or occupational illness. Its role for the prevention of work accidents and occupational illnesses and during rehabilitation is usually emphasised alongside this. The benefits are provided by mutual accident insurance institutions (funds); there are tens of these in Germany today (after multiple mergers). Every enterprise always belongs to a single accident insurance fund. The public sector in Germany now has the same benefits and the costs are defrayed from the institution's budget, i.e. without the assistance of social insurance. 
Austria has a more rationalised social insurance system: the three branches of social insurance are accident, sickness/health and pension insurance - Figure 1 characterises the division of the social insurance up to 2018. Accident insurance is depicted on the left of the picture. The AUVA is the General Work Accident Insurance Institution. This insurance cover is also provided by the Insurance Institution for the Austrian Railways \& Mining Industry (the mining sector is also served by the AUVA), the Social Insurance Institution for Farmers and the Insurance Institution for Public Service Employees.

A significant institutional reform of Austrian social insurance was implemented from 2020: the number of social insurance institutions was reduced from 21 to 5 , of which 3 institutions specialise in pension insurance (Pension Insurance Institution, PVA) and in health and sickness insurance (the Austrian Health Insurance Fund replaced 9 regional and 5 company sickness insurance funds), while the AUVA was least affected by the reform. In addition to these institutions/funds for the three branches of social insurance, there are only two independent providers of the overall social insurance: 1) for the self-employed and 2) for public sector employees, railways and mining. Thus, there is one less social insurance provider in the social accident insurance sector this year.

Figure 1: Organization of the Austrian social insurance institutions in 2018

\begin{tabular}{|c|c|c|}
\hline Work accident insurance & Health insurance & Pension insurance \\
\hline $\begin{array}{l}\text { General Work Accident } \\
\text { Insurance Institution } \\
\text { (AUVA) }{ }^{1}\end{array}$ & $\begin{array}{l}9 \text { regional health } \\
\text { insurance funds } \\
5 \text { Company health } \\
\text { insurance funds } \\
\text { Social Insurance }\end{array}$ & $\begin{array}{l}\text { The Pension Insurance } \\
\text { Institution } \\
\text { itution for Businesses }\end{array}$ \\
\hline \multicolumn{3}{|c|}{ Insurance Institution for Railways and Mining (VAEB) ${ }^{1}$} \\
\hline \multicolumn{3}{|c|}{ Social Insurance Institution for Farmers } \\
\hline \multicolumn{3}{|c|}{ Insurance Institution for Public Sector Employees } \\
\hline & & $\begin{array}{l}\text { Insurance Institution of } \\
\text { Austrian Notaries Public }\end{array}$ \\
\hline
\end{tabular}

Source: BMASGK (2018)

In 2017, the Austrian insurance contribution for social accident insurance amounted to $1.3 \%$ of wages, while it has been $1.2 \%$ of wages since 2018 (up to an earnings ceiling of $€ 5,370$ per month in 2020). The insurance contribution is paid by employers. No insurance contributions are paid for individuals over 60 years of age. Self-employed individuals pay a fixed rate of $€ 10.09$ per month with the option of arranging additional insurance. No insurance contribution is paid for children at kindergarten, pupils and students, whereby the AUVA receives money from the Family Burdens Equalisation Fund (Familienlastenausgleichsfonds, FLAF) to partially cover the payment of the benefits. 
The FLAF fund, administered by the Ministry of Finance, especially pays out universal child allowances (via the local tax offices) and its main source of funds comes from the contributions paid by employers at a current rate of 3.9\% of wages. Otherwise, Austria also has unemployment insurance provided by the Public Employment Service (Arbeitsmarktservice, AMS), which is also responsible for active labour market policy; in this case, the insurance contributions are paid by both the employees and the employers: $3 \%$ of wages each. All the insurance contributions have been reviewed by a single institution (Lohnabgabenprüfbehörde) since 2019, while a further step should involve the introduction of a uniform insurance contribution collected by a new administration for wage levies (Lohnabgabenbehörde).

The transformations in the Austrian social insurance system point to the developmental tendency of the Christian-democratic social model, into which social accident insurance is also fully incorporated, mainly in the form of the unification of the accident insurance premium rate for all employees (regardless of any differentiation of risk according to the professional branch) and the incorporation of this insurance contribution into a single collection point.

"Cross-sectional" social accident insurance makes sense only, if it provides higher benefits than the appropriate "branch-based" (sickness, pension) social insurance or if it provides these benefits under less stringent conditions (for example, regardless of the period of insurance). In Germany, an employee draws full pay for every case of incapacity to work throughout the period of the first 6 weeks. As such, there is zero room for an accident insurance benefit. The rate of the accident sickness benefit (Verletztengeld) is $80 \%$ of the gross wage, but up to a maximum of $100 \%$ of the net wage, for 6 weeks of incapacity to work. Moreover, (none of the) social accident insurance benefits are taxed. The rate for regular sickness benefit (Krankengeld) is $70 \%$ of the gross wage, but up to a maximum of $90 \%$ of the net wage. After receiving an accident sickness benefit, an insured individual may subsequently receive an accident pension (Unfallrente), which amounts to $2 / 3$ of the average wage in the year before the accident in the case of $100 \%$ disablement. Survivor pensions (derived from the wage of the deceased) and a funeral benefit are also paid out in the case of a work injury.

In the Christian-democratic social model, compensation according to the Civil Code is applied only, if the employer has deliberately caused the work accident. Only in this case there is an entitlement to damages for pain and suffering.

The concept for social accident insurance which constitutes part of the Christian-democratic social model provides higher benefits or the same benefits under other more advantageous conditions than is the case in social sickness/health and pension insurances. The reduction of the number of accident insurance funds and other social insurance institutions is usually a long-term process. 


\section{The social-democratic social compensation model}

The social-democratic social model uses mainly a universal system of social security, including healthcare. This includes a universal insurance premium rate for work accidents and occupational illnesses collected from employers en bloc along with other insurance contributions, which are quite similar to a general tax.

In Sweden, cash benefits pertaining to accidents are regulated by the Occupational Injury Insurance Act (1993), the system is administered by the Swedish Social Insurance Agency (along with other cash benefits, except of old-age pensions). It provides a regular sickness benefit in the amount of $80 \%$ of the wage throughout the period of the first 180 days of incapacity to work because of a work accident or an occupational illness. This is initially paid for by the employer (the first 2 weeks, 1 waiting day) and then subsequently from sickness insurance. The benefits from the universal insurance of work accidents and occupational illnesses (arbetsskadeförsäkringen) then come into play: a temporary invalidity pension at the amount of the regular sickness benefit and a permanent accidentbased invalidity pension at the amount of $100 \%$ of the lost earnings. (All insurance benefits are taxed.)

In the case of death as a consequence of a work accident or an occupational illness, a universal funeral benefit and survivor pensions are paid out. The survivor pensions may not exceed the total amount of the pension which the deceased would have been entitled to at the time of death. The survivor pensions include an entitlement to an orphan pension at the amount of $40 \%$ of the permanent accident-based invalidity pension for the first orphan and $20 \%$ of the same pension for each other orphan. Accident-based survivor pensions may also include a widow/widower pension at the amount of $45 \%$ of the same pension, if there are no orphans, or $20 \%$ with one orphan. The accident-based widow/widower pension is paid out for a period of 12 months with the exception of the case where the widow/widower is taking care of an orphan who is under 12 years of age. Accident-based survivor pensions are therefore insurance benefits, unlike the general orphan benefit which is a universal benefit (SSA, 2018).

All employers in Sweden pay statutory social security contributions amounting to 31.42 percent of gross salary and taxable benefits with this structure: retirement pension $(10.21 \%)$, survivor pension $(0.60 \%)$, sickness insurance $(3.55 \%)$, occupational injury insurance $(0.20 \%)$, parental insurance $(2.60 \%)$, unemployment insurance $(2.64 \%)$, general employment tax (11.62\%) (Finfa, 2019). These social security contributions are collected as a whole and are also used as a general economic and social policy tool, which also contributes to the fact that $60 \%$ of the contributions are officially interpreted as taxes (Skatteverket, 2016). E.g. New Start program encourages companies to hire people who have been long-term unemployed - by the exemption from statutory contributions (Business Sweden, 2019). Employers in certain sectors located in specified regions may be entitled to a special reduction of the social security contributions; the reduction amounts to $10 \%$ (Deloitte, 2016). 
The Swedish occupational injury insurance is organized to function as an integral part of the framework of Swedish national social security, receiving contributions from employers and a basic funding through government revenue sources. The objective of occupational injury compensation, according to the law, is to compensate for loss of income and for assessed loss of earning capacity. In addition, a large part of the labour market has a supplementary system, based on collective agreements between the social partners on the labour market (employers organizations in the public and private sectors and corresponding trade unions) for compensation to the insured population for pain and suffering, disability and handicap and other types of incapacity. This collective insurance programme is referred to as the Labour Market No-Fault Liability Insurance (TFA). It operates on a no-fault basis, meaning that, for recognition of a claim, there is no requirement on the claimant to prove negligence on the part of the employer or anyone else involved in the claim at issue. This supplementary insurance system is not required or regulated by law and is operated jointly on a partnership basis by the employers' organizations and the trade unions (Westerholm, 2011). The original purpose of this contractual insurance was a full compensation for loss of income and for costs arising from nonpecuniary damage and, in the case of death, compensation for loss of support and funeral costs, under the norms of tort liability law (Strömbäck, 2001).

The social-democratic social model uses universal insurance and non-insurance benefits, which also include the insurance benefits in the case of work accidents and occupational illnesses which are closely coordinated with the sickness and invalidity insurance benefits. These benefit systems may be further supplemented with occupational schemes. It is possible to waive some of the special accident benefits, if the general (non-accident) benefits are high: this has occurred in the Netherlands since 1967. The Dutch employers are required by law to pay $70 \%$ of the wage for the period of the first 104 weeks of the illness or invalidity. Most collective bargaining agreements state that the employer will pay $100 \%$ of the wage for the period of the first 52 weeks of illness or invalidity. (Many employers cover this risk with private insurance.) The room for special insurance benefits for work accidents and occupational illnesses is therefore very limited in the Netherlands.

\section{The neo-liberal social compensation model}

The neo-liberal theory requires the privatisation of public social security systems. This is intended to essentially limit the (supposedly) inherently ineffective state social policy when compared with the market system. According to neo-liberal theory, the role of the state is to create the basic prerequisites for the market to function (effectively). This is the basis for the orientation of neo-liberal policies towards compulsory employer liability insurance for any damages arising from a work accident or an occupational illness provided by the private sector.

We find the neo-liberal compensation system in the USA; it is called workers' compensation insurance (WCI). Most US states use this system; work accidents and occupational illnesses in the USA fall under the jurisdiction of the states; the federal government takes care of its own employees in this regard only. Except for two of the US states, employers may request to opt out of this compulsory system by stating that they have enough funds to provide 
compensation for any eventual damages (self-insurance). The insurance contracts usually involve the employer's co-payments for any compensation of damages. Private insurance companies with (the appropriate) license in a given US state do not have to comply with a company's proposal to conclude an insurance policy for this type of insurance. The individual US states in question have mechanisms for the assignment of the companyclient in the case of any such "uninsurability", which may also include the creation of a coinsurance contract. Some states have a special state fund (insurance company) for this purpose. Only Texas has no compulsory WCI. Some branches of the economy (for example banking and the insurance industry) have been omitted from the WCI. Small employers and some employees, for example in agriculture and households, constitute slight exceptions to the insurance obligation (Baldwin and McLaren, 2016). According to older data, the total share of private insurance companies in this market throughout the entire USA is about $50 \%$, while the share of state funds is about $20 \%$ and self-insurance accounts for about $25 \%$.

The most important benefit from American WCI employee compensation involves the cover of the healthcare costs, which are provided to the employees at the extent of $100 \%$, i.e. without any co-payment, which is an essential difference in the insurance cover in comparison with US neo-liberal health insurance. There is also an essential difference here in the compensation for loss of earnings, whereby waiting periods are used (typically 3 to 7 days) which may subsequently be cancelled in the case of a long period of hospitalisation or long-term incapacity to work.

The replacement ratio of the compensation to the wage differs in the individual US states, but the average value is around two thirds of the gross earnings. The relatively low replacement ratio is explained on the one hand by the fact that the compensation is not taxed as income and furthermore by the intention of providing motivation for the employee to return to work. Individual US states used to set minimum and maximum compensation values in relation to the average state-wide wage. If an employee is simultaneously entitled to a compensation pension and an invalidity pension from the federal Social Security Disability Insurance (SSDI) system, the total amount of both benefits may not exceed $80 \%$ of the individual's wage prior to the work accident: in most states, it is the compensation pension which is reduced. The compensation pension can be paid out until the end of the recipient's life in most states. The payment of the compensation pension in other states is limited by age or by a maximum payment period or a total benefit amount with the justification, for example, that this involves wage compensation and that the recipient would therefore no longer be in gainful employment upon reaching a certain age, even if he or she had not suffered a work accident or an occupational illness.

The survivor pension is usually paid out to the spouse and orphans at the amount of the compensation pension, which the deceased would have been entitled to. A funeral benefit constitutes a part of the compensation as well.

If employees in the USA accept workers' compensation for a work accident or an occupational illness, they waive any (eventual) entitlement to compensation on the basis of the general responsibility of the employer for the damages caused (tort liability). This is usually designated as the "grand bargain" between the employee and the employer. 
The total compensation provided from insurance in 2015 represented an average of $0.86 \%$ of wages, while the total costs to employers were $1.32 \%$ of wages (Szymendera, 2017). "The Social Security system is a major if not the primary source for insurance for workplace disabilities... Federal funding of workers' compensation is at least four times that of state programs (See Table 1)... Many reformers contend that the state workers' compensation system should be discontinued in favour of a national program with uniform coverage of health care and wage-loss benefits. There have been few calls to federalize the state workers' compensation systems in recent years. The public debate does not appear to be necessary. Most of the responsibility for compensating disabled workers already resides in the federal government, not in the state systems. The federal government not only pays for most workers' compensation benefits, it operates its own array of programs that have considerably more generous benefits than are offered by the state programs" (Sengupta et al., 2010).

Table 1: U.S. Workers' Compensation (WC) Costs, 2008, in billions

\begin{tabular}{|l|c|c|c|c|}
\hline & State WC Programs & Federal WC Programs & Medicare/ Medicaid & SSDI \\
\hline Cash benefits & 28.1 & 29.8 & & 109.0 \\
\hline Health care & 26.1 & 25.0 & 63.6 & \\
\hline
\end{tabular}

Source: Sengupta et al., 2010)

Neo-liberal compensation systems are economical with regard to the number and amount of the benefits, but at the same time they must also be in line with the overall social security system in the given state, which is not always simple and can lead to significant overheads in this system. A specific feature of the American system is the key significance of healthcare which is given by the neo-liberal concept which applies to the main system of the provision and financing of healthcare.

\section{Fundamental reforms of the social compensation system on the territory of Czechia and Slovakia}

The workers' compensation is the oldest type of social security in Czechia as well. The social accident insurance of workers was introduced here by law in 1889 and it was expanded to include occupational illnesses in 1932. Workers' social accident insurance, as an independent branch of social insurance, covered the risk of a work accident relatively comprehensively. The entire benefit system fell under the Christian-democratic social compensation model. In 1948, this (segmented) independent provision of compensation in the case of work accidents and occupational illnesses was transformed into incremental benefits to the (almost universal) national pension and sickness insurance scheme; we may define it as a supplementary social accident insurance from an economic point of view. Social insurance was seen as a "bourgeois relic" in the 1950s. As part of the communist transformation of the system of national insurance and employment law, the benefits paid out upon the occurrence of work accidents and occupational illnesses at state enterprises and institutions over and above the framework of the basic sickness and pension provisions 
were incorporated into the Labour Code. This therefore meant a transition to a system where the socialist organisations were liable for any damages during work accidents and occupational illnesses. The system of so-called central plan-based management enabled the cancellation of these benefits as insurance benefits. The state would step in, if a state enterprise or institution of the day was unable to pay any claimed benefits in the case of work accidents and occupational illnesses; for example, the state plan could also be appropriately "modified", as were the financial relations to the state budget. Cooperatives were not afforded the same guarantee and that is why the state enabled them to conclude insurance policies against liability for damages caused by work accidents and/or occupational illnesses with the State Insurance Company. As such, the Czech State Insurance Company had a portfolio of policies for this type of insurance, which it had concluded with cooperatives, in 1990.

The deliberate exaggeration of the role of simple work was typical for the communist regime and this also found its reflection in the compensation for work accidents and occupational illnesses and in its relation to compensation provided during the application of the principal of liability according to the Civil Code. A more advantageous regimen applied in the case of compensation according to the Labour Code, albeit that the general legal logic of compensation was the opposite, i.e. the provision of compensation for the entire caused injury was fully justified when applying the principle of liability according to the Civil Code. On the other hand, a narrower range of benefits is usually used when applying the principle of strict liability elsewhere in the world and the benefits need not reach the full amount of the injury. Under the conditions of the principle of strict liability, the injured party usually receives less, but does not have to substantiate the fact that the second party is at fault. In other words, there is essentially greater certainty, but with lower benefits. However, this differentiation did not play any significant role given the social protection instituted by the communists and this provided room for the preference of compensation for work accidents and occupational illnesses over the provision of compensation for any detriment according to the Civil Code. The advantage lay in the wider range of types of compensation and also in the higher amounts of some of the benefits.

The Communist social compensation model is still used in Czechia in this regard. According to section 269 of the Labour Code, an employer is obliged to compensate the employee for any damages or non-material detriment which arises as a consequence of a work accident, if the damages or non-material detriment have occurred during the performance of the individual's work tasks or in direct association with them. Accident benefits include:

1. compensation for any loss of earnings throughout the period of incapacity to work,

2. compensation for any loss of earnings after the period of incapacity to work,

3. compensation for any pain and suffering and impaired social engagement,

4. compensation for any costs outlaid in association with healthcare treatment,

5. compensation for material damages,

6. compensation for commensurate funeral costs, 
7. compensation for the costs for the upkeep of any survivors,

8. one-off survivor compensation.

The absolute majority of state enterprises underwent privatisation after 1989 and as such the regulation of the provision of benefits for work accidents and occupational illnesses had to be changed. In some ways, the introduction of the "statutory liability insurance for damages arising from work accidents and occupational illnesses", which followed on from the existing voluntary (albeit de facto fully utilised) liability insurance of cooperatives, constituted the simplest fast solution. The "compensation" (benefits) conceived by the communists was preserved and the financing was assumed by the state budget which immediately then outsourced the "statutory insurance" agenda to two private insurance companies: it awarded its existing clients (and their legal successors) to the Czech Insurance Company (Česká pojištovna) and all newly established enterprises and institutions to the two co-operative insurance companies (Czech and Moravian-Silesian) Kooperativa companies. The share of Kooperativa in this "market" is currently about $80 \%$ (Ducháčková, 2015).

According to the Czech Insurance Association, the premiums written for this type insurance amounted to CZK 7.6 billion in 2017, while the benefits were reported at the amount of CZK 4.8 billion. The surplus for the state budget therefore amounted to CZK 2.5 billion. According to the Ministry of Finance, it is not possible to characterise this insurance as a private insurance. Furthermore, its main shortcoming according to the Ministry lies in the fact that it is realised by two private insurance companies (MF ČR, 2018). The insurance premium schedule dating from 1993 contains 7 rates: 2.8\%o, 4.2\%o, 5.6\%o, 7\%o, $8.4 \%$ o, $10.5 \%$ and $50.4 \%$. This schedule should be regularly reviewed under an insurance system. However, the fees for outsourcing or the normative "administrative costs" of the insurance companies have hiked significantly: from the original $29.5 \%$ to $13.5 \%$ (2004 to 2011 ), to $9 \%$ (up to 2014) and to the current $4 \%$.

The legislation regulating the statutory employer liability insurance for damages in the case of work accident and occupational illness was considered to be a temporary solution at the time of its creation in 1992, acceptable to apply until the Workers' Compensation Insurance Act was passed. A similar approach was also adopted in Slovakia at that time with the main difference being that the statutory insurance was outsourced to one private (Slovak) insurance company only.

The Slovak Social Insurance Act, which has been valid since 2004, included accident insurance ("as insurance against the case of damage to health or death as a consequence of work accident and occupational illness") among the 5 social insurance branches provided by the Social Insurance Institution. At the same time, the entire area of the provision of compensation for work accidents and occupational illnesses was transferred to the social accident insurance from the Labour Code. The following benefits are provided from this accident insurance (Jendrálová, 2004):

a) additional accident allowance (formerly compensation for loss of earnings throughout the period of incapacity to work), 
b) accident pension (formerly compensation for loss of earnings after the conclusion of the period of incapacity to work),

c) one-off settlement (new),

d) survivor accident pension (previously compensation for the costs of upkeep for survivors),

e) one-off compensation (previously one-off compensation to the spouse and the children),

f) occupational rehabilitation and rehabilitation benefit (new),

g) requalification and requalification benefit (new),

h) compensation for pain and suffering and impaired social engagement (the same as before),

i) compensation for the cost associated with healthcare treatment (as before),

j) compensation for funeral costs (as before).

The employer pays insurance premiums at the amount of $0.8 \%$ of wages. The inclusion of accident insurance in the Slovak Social Insurance Act has not changed the objective responsibility of an employer for any work accident suffered by its employees, regardless of the degree of culpability. In the case of hospital treatment and subsequent incapacity to work, the health insurance company always applies recourse against the employer at the amount of $100 \%$ of the healthcare costs outlaid by the health insurance company and the Social Insurance Company recovers all of the paid out sickness benefits from the employer. It is possible to insure against these sanctions within the framework of general liability insurance.

The Czech Workers' Compensation Insurance Act was adopted in 2006 and it was scheduled to come into force from 2008. The accident benefits continued to be based on the communist social compensation model, but the names of the benefits had been modified (and rehabilitation had been added to them) basically according to the aforementioned Slovak design. For example, compensation for loss of earnings throughout the period of incapacity to work was replaced with an additional accident allowance. The deduction of sickness and pension insurance benefits in the calculation of any accident benefits remained in place. As such, this involved de facto supplementary social accident insurance. The Act placed a great emphasis on the prevention of damages and the projection of the loss experience into the amount of the insurance premiums paid by the individual employers. The workers' compensation insurance agenda was supposed to fall under the aegis of the Czech Social Security Administration (and its district administrations); the revenues and expenditures were supposed to form part of the revenues and expenditures of the state budget.

The effective date of the Workers' Compensation Insurance Act was repeatedly deferred, mainly under the influence of lobbyists (Šedivec, 2015). The first deferment was proposed by the Topolánek government which "wanted to reopen the debate as to which accident insurance system should actually be chosen" (ČTK, 2009). "The government decided to defer the Act's effective date by three years, because the implementation of the new legal 
regulation of accident insurance would place significant demands on the state budget. The launch of the new system would also be associated with an incommensurate organisational burden on the Czech Social Security Administration not only from the point of view of its staff, whereby it would need to take on several hundred new employees but especially from the point of view of the technical aspects. Likewise, it is also not yet sufficiently clear as to whether the as-yet ineffective, but currently valid regulation truly represents the last word or whether it will be replaced with another" (Beck, 2009). “. . discussions have been held on this topic since the beginning of the 1990s with the same arguments and essentially with the same types of basic solutions. Whenever a decision has been reached, it has always depended more on political arguments than factual ones. The justifications, which have often been based on merely superficial knowledge of the individual systems or have even bordered on demagogy, have also been adapted to this fact" (Přikryl and Čechová, 2014).

In 2012, the Nečas government's Ministry of Finance of the Czech Republic drew up a proposal for the privatisation of workers' compensation insurance. "Our idea conforms to the liberal approach which this government has applied to all areas. The solution which we are proposing in the case of workers' compensation insurance is based on free competition among the insurance companies and also on the obligation of employers to conclude such insurance cover for their employees. This will ensure that all employees will be guaranteed compensation for any losses which they incur as a consequence of a work accident or an occupational illness, but the competitive element will mean that this will be achieved for the best price", said Deputy Minister Urban, before continuing: "one of the features of the prepared change involves the fact that we intend to use the experience which we have acquired from the de-monopolisation of the no-fault auto insurance. We are convinced that this will lead to similarly good results, i.e. to competitive offers corresponding to the segmentation according to the actual risk and to low prices. Both employers and employees will benefit from this" (Šístková, 2012). An Office of Work Accident Insurers was also meant to be established along the lines of no-fault auto insurance. There were also proposals for the establishment of a public accident insurance company and for accident insurance to be administered by the health insurance companies (Přikryl and Čechová, 2014). The Czech Ministry of Labour and Social Affairs then presented an amendment to the Workers' Compensation Insurance Act against the backdrop of this state of affairs... and all the dissatisfied parties, including the unions, used it to reject this amendment and the entire concept of the valid, albeit ineffective Workers' Compensation Insurance Act, for example at the "Prerequisites for the Functioning Accident Insurance of Employees in the Czech Republic" conference which was held in the building of the Senate of the Czech Republic in January 2012. The two main reasons why the participants at this conference disagreed with the entire concept of the Act were that:

* "At its very core, accident insurance should involve the liability insurance and not the social insurance.

* The insured party must be the employer, who is responsible for the damage to health as a result of a work accident or an occupational illness, and not the employee" (Hrubá, 2012). 
Propositions of this type demonstrate a one-sided view of social accident benefits which is fully in line with the neo-liberal model. However, the criticism from the conference participants did not necessarily proceed any further in this direction. Perhaps everybody wanted to preserve the communist concept of the preference for compensation according to the Labour Code over that based on the Civil Code; however, this is precisely the opposite of what occurs in all modern social compensation models. Given this state of affairs, it is no wonder that the Workers' Compensation Insurance Act was annulled after all.

The Czech system of statutory employer liability insurance for cases of work accidents and occupational illnesses is unique in the world, because two private insurance companies are (the only) parties involved in the collection of the insurance contributions, the settlement of the insured events and the payment of the insurance benefits: they settle these revenues and expenditures with the Ministry of Finance every year in return for a fee. Any reformoriented efforts are currently "dormant".

\section{Discussion}

The Czech system of statutory employer liability insurance for work accidents and occupational illnesses can be characterised as a universal system of supplementary social accident insurance from the point of view of modern social models. This conclusion of the previous analyses alone witnesses the inconsistencies in this Czech subsystem of social security. It is admittedly legitimate to require accident insurance to involve employer liability insurance for work accidents and occupational illnesses, but only if we require the realisation of a neo-liberal social compensation model. In that case, we should, of course, also require economical accident benefits like those used in the USA, for example. In any case, this approach is in stark contrast to the communist concept of benefits which went over and above the framework of the compensation according to the Civil Code which is inseparably bound with the tort system. If expertise wins out over populism and lobbying, both extreme approaches (neo-liberalism and communism and the mix thereof) should be rejected.

In any case, (supplementary) social accident insurance should not be regulated by the Labour Code. At the same time, it is also clear that it would be wrong to transfer the entire regulation of this area to the Workers' Compensation Insurance Act which was supposed to come into effect in 2008 (with only cosmetic alterations, including the expansion of the range of benefits to 10 entries). In this regard, we can certainly agree that compensation for material damages (for example the destruction of clothing) and compensation for commensurate funeral costs do not belong in (supplementary) social insurance: employers can "manage" to compensate them without statutory insurance. Compensation for pain and suffering and impaired social engagement and any similarly conceived one-off survivor compensation also do not essentially belong to (supplementary) social accident insurance. "Common occupational insurance systems based on workers' compensation insurance... rarely provide full compensation for injuries as the compensation amount paid usually reflects reasonable economic losses, while non-economic losses (such as pain, suffering, psychical losses) are rarely compensated" (Pecillo, 2017). 
Given the overall system of Czech social security, it is not possible to consider cancelling the statutory insurance, as has been done in the Netherlands, for example. The net replacement ratio in the case of sickness benefit in Czechia falls within the range of $71.2 \%$ (the 15th to 30th day of incapacity to work) to $85.5 \%$ (from the 62 nd day of incapacity to work) in the case of an employee with average earnings. There is therefore a significant amount of room for supplementary social accident insurance. This applies all the more so in the case of an accident invalidity pension (or compensation for loss of earnings after the completion of the period of incapacity to work). If the sickness benefit and invalidity pension underwent the necessary modernisation, it would be possible to replace any "compensation for loss of earnings" with a higher rate of sickness benefit and invalidity pension in the Sickness Insurance Act. (In the case of invalidity pensions, we propose that they be reassigned from pension to sickness insurance.) It is similarly possible to transform the compensation for the costs of the upkeep of survivors into an aggregate survivor accident pension or a widow/widower accident pension and an orphan accident pension. The optimal solution involves the taxation of all insurance benefits: then the rates for accident sickness benefit and accident invalidity pension would be $100 \%$.

The compensation for any costs outlaid in association with healthcare could be cancelled with any reform of the statutory insurance given the low degree of patient co-payments in the financing of healthcare in our country. We also do not need rehabilitation as a separate accident insurance benefit as everybody should have the same entitlement to rehabilitation (and not only in the case of a work accident).

The liquidation of the remnants of the communist system of compensation for work accidents and occupational illnesses is politically demanding, but it would be expedient to prepare it and then to realise it at a suitable moment. One relatively easily achieved operation could be the full or essential unification of the insurance premium rates for the current statutory employer liability insurance for damages arising in the case of a work accident or an occupational illness and its inclusion in the insurance contributions paid by the employer. An expert argument for the unification of the accident insurance premium is the predominant (70\%) tax nature of the insurance contribution for "pension insurance" (with a $28 \%$ rate). The insurance contributions for public health insurance with a rate of $13.5 \%$ of wages fully constitute a tax by nature. In comparison with this, the efforts to preserve the differentiation of the accident insurance premium rates are somewhat extravagant, not to mention the efforts aimed at the introduction of bonuses and extra premiums. The insurance premiums for supplementary social accident insurance can be reduced (from the current average of $4.5 \%$ of wages) and "dissipated" into sickness, pension and even health insurance premiums.

The basic weakness of the Workers' Compensation Insurance Act of 2006 was in its mechanical adoption of the existing (post)communist system of providing compensation for work accidents and occupational illnesses. Given the existing level of universal (social) sickness and pension insurance and universal healthcare in the Czech Republic, it would be easy to realise the basic form of the social-democratic social compensation model using the structure of the Czechoslovak National Insurance Act of 1948: all four (earnings-related) accident insurance benefits, i.e. accident sickness benefit, invalidity accident pension, 
widow/widower accident pension and orphan accident pension, can be transformed into a higher rate of sickness benefit and three pensions. The insurance contributions for the current statutory employer liability insurance belong to the concept of a single collection point for social and health insurance contributions.

\section{Conclusion}

Modern theory and policy differentiate between four basic social models of benefits in the case of work accidents and occupational illnesses. The basic element of the modern liberal system involves relatively low universal benefits, including the case of a work accident or an occupational illness. The essential element of the British Beveridge model is universal healthcare provided by the National Health Service. Employees may also be entitled to occupational benefits in the case of incapacity to work. The low level of benefits in British practice has led to the introduction of compulsory employer liability insurance. The neo-liberal social compensation model is based on the compulsory liability insurance of employers which, under American conditions, mainly meets all the costs for healthcare which are often not covered by compulsory private health insurance with its frequently high client co-payments. Segmented social insurance of accidents and occupational illnesses is typical for the Christian-democratic social compensation model, whose most distinctive representative is accident insurance as an independent branch of social insurance which provides full sickness/healthcare and pension benefits. This Bismarck model of social accident insurance was applied in our country until 1948 when a move was made towards a system of increased sickness and pension benefits in the case of work accidents and occupational illnesses under the National Insurance Act.

The social-democratic model is characterised by universal public healthcare and universal insurance benefits which may (but need not) fully compensate for any loss of earnings in the case of a work accident or occupational illness. The replacement ratio may be further increased on the basis of a system of employer liability insurance for damages arising from work accidents and occupational illnesses. Special accident benefits are pointless in the case of very high compensatory ratios, as in the Netherlands, for example. The communist social accident model rejected social insurance (on ideological grounds) and preferred manual work which was reflected in the compensation of work accidents and occupational illnesses over and above the framework of the compensation for damages or detriment according to the Civil Code. As such, the system of thus preferred compensation according to the Labour Code has been preserved in our country to the present and it was included in the "temporary" statutory employer liability insurance for work accidents and occupational illnesses, which the state has outsourced to two private insurance companies, after 1989. This has not occurred anywhere else in the world. The adoption of the Workers' Compensation Insurance Act and the repeated deferment of its effective date bear witness to the strength of the lobbyists and the ability of Czech politicians to decide in favour of one or another social model. Given the current state of affairs, rational and gradual reform steps which follow on from other social reforms (for example the concept of a single point of revenue collection) or from the rationalising reform of income tax, social 
insurance premiums and health insurance premiums are required. We need to reform the pension, sickness and health insurance schemes: we do not need a Workers' Compensation Insurance Act.

\section{Acknowledgements}

The paper was created by using institutional support for long-term conceptual development of research of the University of Finance and Administration.

\section{References}

Baldwin, M. L., McLaren, Ch. F. (2016). Workers' Compensation: Benefits, Coverage, and Costs. Washington: National Academy of Social Insurance. Retrieved June 24, 2019 from https://www.nasi.org/sites/default/files/research/NASI_Workers_Comp_Report_2016.pdf. Beck. (2009). Sněmovna schválila novelu zákona o úrazovém pojištění zaměstnanců. Beck-online. Retrieved June 24, 2019, from https://www.beck-online.cz/snemovna-schvalila-novelu-zakona-o-urazovem-pojisteni-zamestnancu/.

BMASGK. (2018). Social Protection in Austria. Benefits, expenditure and financing 2018. Austrian Presidency of the Council of the European Union. Vienna: Federal Ministry of Labour, Social Affairs, Health and Consumer Protection (BMASGK). Retrieved June 24, 2019, from https://www.sozialministerium.at/cms/site/attachments/4/7/1/CH3434/CMS1533894817584/socialprotections2017_web_v3k3.pdf.

Business Sweden. (2019). The Swedish Social Security System. Stockholm: Business Sweden. Retrieved June 24, 2019, from https://www.business-sweden.se/globalassets/invest-new/reports-and-documents/establishment-guides/the-swedish-social-security-system_march 2019.pdf.

ČTK. (2009). Stát zatím nepřevezme odškodňování zaměstnanců za pracovní úraz. Retrieved June 24, 2019, from https://www.novinky.cz/kariera/176682-stat-zatim-neprevezmeodskodnovani-zamestnancu-za-pracovni-uraz.html.

Deloitte. (2016). Sweden: Taxation and Investments. Retrieved June 24, 2019, from https:// www2.deloitte.com/content/dam/Deloitte/cn/Documents/international-business-support/ deloitte-cn-ibs-sweden-tax-invest-en-2016.pdf.

Ducháčková, E. (2015). Insurance of Work-related Injuries in the Conditions of the Czech Republic. Procedia Economics and Finance, sv. 25, s. 200-207. Retrieved June 24, 2019, from https://www.researchgate.net/publication/282417266_Insurance_of_Workrelated_Injuries_in_the_Conditions_of_the_Czech_Republic.

Esping-Andersen, G. (1990). The Three Worlds of Welfare Capitalism. Cambridge: Polity Press \& Princeton: Princeton University Press.

Finfa. (2019). Statutory and collective insurance schemes for the Swedish labour market 2019. Fortieth revised edition. Finfa - part of the Confederation of Swedish Enterprise. Retrieved June 24, 2019, from https://www.svensktnaringsliv.se/migration_catalog/Rapporter_och_opinionsmaterial/Rapporter/statutory-and-collective-insurance-schemesswedish-labour-market_732029.html/BINARY/Statutory-and-collective-insurance-schemes-Swedish-labour-market-2019.pdf. 
Hrubá, K. (2012). Zrušení zákona o úrazovém pojištění zaměstnanců. Retrieved June 24, 2019, from https://www.bozpinfo.cz/zakon-o-urazovem-pojisteni-zamestnancu.

Jendrálová, A. (2004). Odškodňovanie pracovných úrazov. Retrieved June 24, 2019, from https://hnonline.sk/expert/34275-odskodnovanie-pracovnych-urazov.

Lewis, R. (2012). Employers' Liability and Workers' Compensation: England and Wales. Cardiff: Cardiff University. Retrieved June 24, 2019, from https://orca.cf.ac.uk/26855/1/ Lewis\%202012.pdf.

Pecillo, M. (2017). International comparison of occupational accident insurance system. OSHWIKI. Retrieved June 24, 2019, from https://oshwiki.eu/wiki/International_comparison_of_occupational_accident_insurance_system .

Přikryl, V., Čechová, J. (2014). Zamyšlení: Nekonečný př́iběh úrazového pojištění zaměstnanců. Pojistný obzor, ročník 91, č. 1.

Sengupta I., Reno V., Burton J. F. (2010). Workers' Compensation: Benefits, Coverage, and Costs, 2008. Washington: National Academy of Social Insurance. Retrieved June 24, 2019, from http://www.nasi.org/research/2010/report-workers-compensation-benefitscoverage-costs-2008.

Skatteverket. (2016). Taxes in Sweden 2015. An English Summary of Tax Statistical Yearbook of Sweden. Swedish Tax Agency, 2016. Retrieved June 24, 2019, from http://www.skatteverket.se/download/18.3810a01c150939e893f29d0f/1455280476021/ taxes-in-sweden-skv104-utgava16.pdf.

SSA. (2018). Social Security Programs throughout the World: Europe. Social Security Administration (USA). Retrieved June 24, 2019, from https://www.ssa.gov/policy/docs/ progdesc/ssptw/2018-2019/europe/ssptw18europe.pdf.

Strömbäck, E. (2001). Sweden's No-Fault Rule for Accidents at Work - Recent Developments. Scandinavian studies in law. Stockholm Institute for Scandinavian Law 1957-2009. Retrieved June 24, 2019, from http://www.scandinavianlaw.se/pdf/41-19.pdf.

Szymendera, S. D. (2017). Workers' Compensation: Overview and Issues. Congressional Research Service. Retrieved June 24, 2019, from https://fas.org/sgp/crs/misc/R44580.pdf. Šedivec. (2015). Jednala Rada vlády České republiky pro BOZP. Retrieved June 24, 2019, from https://www.ospzv-aso.cz/obsah/81/jednala-rada-vlady-ceske-republiky-probozp/3276.

Šístková, D. (2012). Úrazové pojištění zaměstnanců se zpřistupní všem pojištovnám. Retrieved from https://www.opojisteni.cz/pojistne-produkty/urazove-pojisteni-zamestnancu-sezpristupni-vsem-pojistovnam/c:4418/.

Westerholm, P. (2011). Country Case Study: Sweden. In: Rey, P. and Lesage, M. (eds.). Topics in Workers' Compensation Systems. Geneva: ILO. Retrieved June 24, 2019, from http://www.iloencyclopaedia.org/part-iii-48230/topics-in-workers-compensation-systems 136-26-workers-compensation-systems-topics-in/country-case-study-sweden. 